visitor and expressed his gladness at being back with his friends in his usual sincere fashion. The topic of the evening was keenly discussed by a number of the members. Doctors Lowe and Bernstein, Messrs. Peacock, Cliffe, Hunsberger, and Beringer, were particularly prominent in stating their views on the question. The latter four members were able to present views which were peculiarly interesting in that they are four retail pharmacists whose business acumen, as well as their high professional rating, is beyond questioning.

The meeting adjourned at 11.15 and was undoubtedly highly instructive and interesting. IVoR GrIFFITH, Secretary.

\title{
COMMITTEE REPORTS
}

\section{REPORT OF COMMITTEE ON THE U. S. PHARMACOPOEIA, AMERICAN PHARMA- CEUTICAL ASSOCIATION.*}

It has been exceedingly difficult to secure observations, criticism or suggestions from the various members of the committee. The reasons therefor are probably due to the present disturbed conditions, not only in United States, but the world over. There are, however, submitted herewith a number of observations, suggestions and criticism which it is believed will be of service in the working out of the roth decennial revision of the U. S. Pharmacopoeia.

The question of ash content in drugs should receive careful investigation. This material finds its way into the whole and powdered drugs through various avenues. Some of the plants are grown in sandy soil and the silicious matter may be greatly augmented by the simple, mechanical adherence of the sandy matter. The nature of the drugs is sometimes such as to make it very difficult to remove the inorganic matter from the plants either at the time of gathering or subsequently. In many instances the ash content varies greatly with the nature and character of the soil in which the plants are produced. The ash content of the same drugs grown in the same field often varies materially. It is believed all of these factors should be carefully worked out, from the commercial, botanical, analytical and other points of view. It is not believed that with our present limited knowledge very much dependence can be placed upon ash limitations.

The present standard for maximum ash content for rhubarb is $13 \%$. Excellent speciments of whole rhubarb have been met with containing very much higher percentage of ash. In the case of powdered drugs the miller is sometimes looked upon with suspicion when there is really no foundation for such a suspicion and every effort should be made to correct questioned standards, which would tend to reflect unjustly upon manufacturers and dealers.

CANNABIS INDICA: The present physiological method contained in the Pharmacopoeia for testing Cannabis Indica has been subject to repeated criticism. A detailed criticism has been referred to the Committee on Revision. It is believed that the question should receive very careful and thorough consideration.

CRFOSOTE: Manufacturers have repeatedly complained relative to the so-called glycerin test for the alleged detection of "coal-tar creosote" in creosote. The point raised was that this test discriminates against the American-made creosote in favor of imported product. It is believed that this criticism should be carefully investigated and, if found correct, the test should be modified.

Several members of the committee have made suggestions and criticism which are submitted as received and are as follows:

\section{H. ENGELHARDT.}

ACETUM SCILLAE: This preparation should be omitted because it is therapeutically not sufficiently active.

ACID BENZOIC: A more definite test for distinguishing between the natural and synthetic acid should be given.

ACID HYDRIODIC: The residue left after evaporating and incinerating 5 mils of the acid is not potassium carbonate as is usually accepted but is potassium iodide which volatilizes when too high a heat is applied. Therefore it should be stated that the heating should be carried out only at dull redness.

\footnotetext{
* Presented at Chicago meeting American Pharmaceutical Association, 1918.
} 
ACID L,ACTIC: In the assay process it is stated that a certain amount of the acid be poured into a tared and stoppered bottle. How can this be done? The phraseology should be changed.

ACID PHOSPHORIC: It would be advisable to change the assay process which is a very cumbersome one.

ACID SALICYLIC: More definite tests for distinguishing between natural and synthetic acids should be given.

ACID SULPHURIC AROMATIC: The assay process given in the Pharmacopoeia is wrong. It would be advisable to adopt the process published by Penniman and Randall in the Jour. Indus. \&'Eng. Chemistry for October 1916.

ACONITINE: Physiological test of the alkaloid should be given because commercial samples vary very widely in toxicity.

ACONITE AND ITS PREPARATIONS: The assay process should be thoroughly revised as the chemical results are not in proportion to the physiological results. It is impossible to obtain a definite end point when using cochineal as indicator. Methyl red therefore should be used, by which results are obtained which indicate the toxicity of the drug better than the results obtained with cochineal.

CANNABIS: If physiological tests for this drug and its preparation are to be retained a reliable method should be given. The present method gives results which are far from satisfactory.

CAPSICUM: We have found that in some years it is impossible to obtain $15 \%$ of ethersoluble oleoresin from the average commercial drug. The drug seems to be subject to considerable seasonal variation.

CODEINE AND ITS SALTS: Why is only an assay process for Codeine Phosphate given and not for the alkaloid and the sulphate?

CRESOL: Commercial cresol is not always soluble in 60 parts of water.

DIGITALIS: The physiological assay method should be revised and the one-hour frog test preferably be replaced by the I2-hour frog or still better by the cat method.

EMETINE HYDROCHLORIDE: The U. S. P. states that emetine hydrochloride contains variable amounts of water. A properly prepared salt contains about 7 molecules of water of crystallization which would correspond to the $19 \%$ of moisture permitted by the U.S.P.

F. E. PODOPHYLLUM: A standard should be given.

F. E. SQUILL: The manufacturing method should be revised. A detailed paper on this subject will be submitted by Messrs. Grantham and Colson at the Chicago meeting of the association. (Printed in November issue of the Journal, p. 940.)

MERCURY SALICYLATE: The assay process might well be simplified. It can be carried out by treating a weighed amount of the sample with sulphuric acid and nitric acid and titrating the solution thus obtained with potassium sulphocyanide as directed under mercury.

LINIMENT OF CAMPHOR: The limits of the requirements are too narrow considering the difficulties which are encountered in the assay process.

LIQUOR ARSENIC AND MERCURY IODIDE: It has been stated that the arsenic in the arsenous state is easily oxidized into arsenic in the arsenic state. It would therefore be advisable to make in addition to the estimation of the arsenous arsenic a determination of the total arsenic.

LIQUOR CRESOLIS COMPOUND: A method for the estimation of the water in the preparation should be given since this preparation comes under the Insecticide Act which requires a statement of the inert ingredients, in the preparation.

HYDROGEN PEROXIDE: A method for estimating the acidity should be given. By the present method only one-half of the acidity is estimated.

LIQUOR POTASSIUM ARSENITE: The total arsenic in Fowlers Solution should be estimated in addition to the estimation of arsenous arsenic. Under certain conditions an oxidation of the arsenous arsenic to arsenic is liable to occur.

MAGMA BISMUTHI: The electrolytical process should be given as an alternative method. By simply evaporating a definite quantity of the magma to dryness and weighing the residue, soluble salts present in the preparations are estimated also.

OLEATE OF MERCURY: An assay process should be given.

OLEORESIN MALEFERN: An assay process should be given. 
PANCREATIN: The milk test should be omitted.

PODOPHYLLIN: More details of the assay method should be given.

POTASSIUM CHLORATE: Why is test for nitrites and nitrates omitted?

QUININE AND ITS SALTS: Kerner's test as given in the U. S. P. for foreign cinchona alkaloids is too lenient. be given.

RESIN JALAP: Details for estimating the solubility in ether and chloroform should:

SODIUM PHOSPHATE: The assay process is very cumbersome.

SPARTEINE SULPHATE: Assay process should be given.

SPIRIT AMMONIA AROMATIC: The alkalinity should be determined.

STROPHANTHIN: Physiological assay method should be given.

STRYCHNINE AND ITS SAL,TS: Assay methods should be given.

SYRUP OF IPECAC: Why is acetic acid added when the fluidextract already contains. hydrochloric acid?

SYRUP OF SQUILI: Why not make this preparation with fluidextract of Squill?

TINCTURE IODINE: The percentage of alcohol is given at $83 \%$, while theoretically it is $87 \%$.

TINCTURE GINGER: Standard for total solids should be more definitely stated.

UNGUENTUM HYDRARGYRI: Considering the difficulty experienced in making. this ointment the limits for required percentage of mercury should be extended.

E. P. BIGELOW, SUMITTED BY E. H. LAPIERRE.

Impurities in Potassium Carbonate and Bicarbonate.

RECOMMENDATIONS FOR ADDITIONAL U. S. P. TESTS.

During the past twelve years the writer has had occasion, as a matter of routine, to examine a great many samples of high grade Potassium Bicarbonate and for several years many samples of Potassium Carbonate also, and the requirements for the purity for these salts as given in the U.S. P. both 8 th and 9 th revisions have been found inadequate.

The purchaser of products conforming to the U.S. P. standards should at least expect to be safeguarded against the possibilities of dangerous impurities; nevertheless, such is not the case as regards $\mathrm{KHCO}_{3}$ or $\mathrm{K}_{2} \mathrm{CO}_{2}$. These dangerous impurities have been found in $\mathrm{K}_{2} \mathrm{CO}_{3}$. prepared before the War under normal conditions of production and manufacture as well as in that now produced and on the market. Traces of these impurities have been occasionally found in. $\mathrm{KHCO}_{3}$.

The requirements of the $\mathbf{B}$. $P$. on the other hand are more stringent as regards these two salts and with few exceptions are open to but little criticism. For this reason it is to the advantage of the manufacturer to specify $B$. P. instead of U. S. P. when purchasing $\mathrm{K}_{2} \mathrm{CO}_{3}$ or $\mathrm{KHCO}_{3}$.

Based on the writer's experience the most objectionable impurities not provided for in the U. S. P. are as follows:

1. ARSENIC: This has been found in high grade calcined $\mathrm{K}_{2} \mathrm{CO}_{3}$ in amounts varying. from to parts per million to as high as approximately 100-200 parts per million, and possibly even in larger amounts, as the total quantity was not always determined. Certainly an excessive figure, and as $\mathrm{K}_{2} \mathrm{CO}_{3}$ is often used in medicinal preparations the presence of such a product would be fraught with much danger.

Arsenic has been found in $\mathrm{KHCO}_{3}$ in traces only and then usually in the powdered salt. Some hydrated $\mathrm{K}_{2} \mathrm{CO}_{3}$ tested showed ro parts per million. The British Pharmacopoeia (see U.S. Dispensatory, 2oth Ed., page 894) limits the arsenic content in $\mathrm{K}_{2} \mathrm{CO}_{3}$ to 2 parts per million: and in $\mathrm{KHCO}_{3}$ (page 883) to 5 parts per million. The only test in the U.S.P. at all applicable is the "Time Limit 'Test" for heavy metals, which is entirely inadequate for arsenic in such quantities. The writer uses a modified Marsh method with a preliminary treatment of the product with $\mathrm{HNO}_{3}$ and $\mathrm{H}_{2} \mathrm{SO}_{4}$.

2. CYANIDE COMPOUNDS: These may be present in Potassium Carbonate (or possibly bicarbonate) prepared by the Leblanc process in which coal containing appreciable amounts of nitrogen is employed, or from any source where the ignition of nitrogenous matter takes place during the process. Cyanide compounds have been found in quite a number of 
samples of high grade calcined $\mathrm{K}_{2} \mathrm{CO}_{3}$ and in a few cases in appreciable amounts. Preliminary tests indicated ferrocyanide. One sample of a poor grade contained $\mathrm{KCN}$. No cyanides have been found in the samples of $\mathrm{KHCO}_{3}$ examined.

The British Pharmacopoeia allows no characteristic reactions for cyanides in $\mathrm{K}_{2} \mathrm{CO}_{3}$, and Merck, "Chemical Reagents, Their Purity and Tests," 1914, page 129, provides a test for $\mathrm{KCN}$ in $\mathrm{K}_{2} \mathrm{CO}_{3}$. Krauch, "Testing of Chemical Reagents," 3rd Ed., on page 225, also gives a test for $\mathrm{KCN}$ in $\mathrm{K}_{2} \mathrm{CO}_{3}$.

The writer employs a modified Prussian blue test which is accurate and sufficiently delicate (except in the presence of chlorates). The test is as follows: Introduce $1.8 \mathrm{Gm}$. of calcined $\mathrm{K}_{2} \mathrm{CO}_{2}$, or 2.8 grammes of $\mathrm{KHCO}_{3}$, into a dry test tube, capacity about 40 mils. Add $0.100 \mathrm{Gm}$. powdered ferrous sulphate (or more if necessary), mix, and next add 4 mils distilled $\mathrm{H}_{2} \mathrm{O}$ and 0.5 mil 10\% $\mathrm{NaOH}$ in the case of the $\mathrm{K}_{2} \mathrm{CO}_{3}$ and 2 mils $10 \% \mathrm{NaOH}$ and $3^{1 / 2}$ mils $\mathrm{H}_{2} \mathrm{O}$ in the case of $\mathrm{KHCO}_{2}$. Then in both cases mix well, put in water-bath (temp. $140-160^{\circ} \mathrm{F}$.) and allow to remain about to minutes, occasionally shaking to insure complete solution. Next add to each tube 2 drops ro\% $\mathrm{FeCl}_{3}$, mix and at once add enough conc. $\mathrm{HCl}$ to render solution slightly acid (add acid very cautiously to avoid loss from effervescence), usually takes about 2.8 to 3 mils.

Examine tubes for ${ }^{1}$ greenish coloration or precipitate, comparing with pure control and one containing a known amount of $\mathrm{KCN}$. Then allow to remain for a few hours or over night, filter through a Whatman No. 44, I I cm. "wetted" filter, wash with water and examine for traces of blue residue of ferric ferrocyanide. This test readily detects $0.00004 \mathrm{Gm}$. $\mathrm{KCN}$ in $\mathrm{K}_{2} \mathrm{CO}_{3}$ and $0.0001 \mathrm{Gm}$. in $\mathrm{KHCO}_{3}$.

The addition of dry powdered ferrous sulphate or the dry sample in the test tube, before adding the alkaline hydroxide solution and water, prevents any interference from sulphur compounds sometimes present in $\mathrm{K}_{2} \mathrm{CO}_{3}$. It is very essential that the test should be filtered, otherwise traces of the blue precipitate are apt to escape detection. The presence of chlorates renders the test unreliable.

3. SULPHOCYANATES: KCNS has been found very frequently in calcined and hydrated $\mathrm{K}_{2} \mathrm{CO}_{2}$ in amounts varying from $0.01 \%$ to as high as $0.09 \%$. Traces have been found in $\mathrm{KHCO}_{3}$.

4. CHLORATES: This impurity may be present in $\mathrm{K}_{2} \mathrm{CO}_{3}$ or $\mathrm{KHCO}_{3}$ prepared from electrolytic $\mathrm{KOH}$. It has been found in amounts varying from traces up to $0.12 \%$ as $\mathrm{KClO}_{3}$. It was detected chiefly in powdered $\mathrm{KHCO}_{3}$ and calcined $\mathrm{K}_{2} \mathrm{CO}_{3}$.

Among the less objectionable impurities are the following:

Ist. Sulphides. Found in traces in $\mathrm{KHCO}_{3}$ and in calcined $\mathrm{K}_{2} \mathrm{CO}_{3}$. Sometimes in appreciable amounts in hydrated $\mathrm{K}_{2} \mathrm{CO}_{3}$. amounts.

2nd. Nitrites. Found frequently in samples of Japanese (so called) $\mathrm{K}_{2} \mathrm{CO}_{3}$ in slight

3rd. Iodides. Found in a number of samples of $\mathrm{K}_{2} \mathrm{CO}_{3}$. Possible source Kelp Ash.

4th. Ammonium Salts. Found occasionally in samples of $\mathrm{KHCO}_{3}$, usually in powdered product.

5 th. Sodium. Almost always present in amounts varying from traces to as high as $10-12 \%$ (as $\mathrm{Na}_{2} \mathrm{CO}_{8}$ ) in $\mathrm{K}_{2} \mathrm{CO}_{3}$, and from bare traces up to $7 \%$ (as $\mathrm{NaHCO}_{8}$ ) in $\mathrm{KHCO}_{3}$. U. S. P.

Such samples containing less than $99 \%$ pure product would of course not conform to the

6th. Sulphates, Chlorides, Phosphates. Frequently present in $\mathrm{K}_{2} \mathrm{CO}_{3}$. Chlorides, also, usually present in $\mathrm{KHCO}_{3}$.

7th. Nitrates. Occasionally present in $\mathrm{K}_{2} \mathrm{CO}_{3}$.

8th. Iron. Almost always present in both $\mathrm{KHCO}_{2}$ and $\mathrm{K}_{2} \mathrm{CO}_{3}$.

9th. Silica and Silicate. Frequently present in $\mathrm{K}_{2} \mathrm{CO}_{3}$. Occasionally. quite heavy in Japanese $\mathrm{K}_{2} \mathrm{CO}_{3}$.

${ }^{1}$ Is blue when washed free from $\mathrm{FeCl}_{3}$. 
With the development of new sources of potash, due to shutting off our main supply, there is of course the possibility of additional impurities as well as those previously existing, such as, for example, iodides from potash from kelp ash, nitrites from (so-called) Japanese potash (both mentioned above) and borax in the Searles Lake product.

The Imperial Institute, London, in a bulletin entitled “The World's Supply of Potash," 1915 , on page 12, gives the analysis of the salts of Searles Lake brine in California and one of the constituents is Sodium Arsenate, $0.17 \%$. If such is the case there may be possibilities from this source.

The suggested use of Calcium Fluoride in connection with the recovery of Cement Dust Potash may mean the presence of Fluorides in the purified product.

SUMMARY.

From the results of analyses of many samples of potassium carbonate and bicarbonate it seems evident that the following tests should be added to the requirements of the U. S. P.

rst. Suitable tests for Arsenic with limit set for amount allowed.

2nd. Test for Cyanide Compounds.

3rd. Test for Sulphocyanates.

4th. Test for Chlorates.

Tests for sulphides, nitrites, iodides, ammonium salts and other less objectionable impurities mentioned above might be considered advisable.

E. Fullerton Cook: "In making the report of the Committee this year, my only suggestion is with reference to the methods for the next revision. As the work progressed on the U. S. P. IX, we became more and more dependent for conclusions upon personal conferences. Often many decisions were reached in this way in one meeting, which would have required months of correspondence under the usual plan.

I hope that the Committee can point out this advantageous method of conducting the work and would be willing to advocate it as a policy for the next revision."

There is no doubt but that much room for improvement exists as regards methods involved in preparing a revision of the U. S. Pharmacopoeia. A procedure that consumes six years to get out a new revision is entirely too long. The time should be cut in half at least. Various plans for doing this have been suggested. One is, as indicated by Professor Cook, to call together in conference the various members of a sub-committee to consider any vital points involved and determine them by this means rather than by a long, tedious method of correspondence. It has been suggested that a permanent central laboratory, conducted by the Pharmacopoeia committee of revision would materially expedite the work and be productive of excellent results.

Considerable agitation has been abroad relative to the revision being made by the Government. It is held that in view of the fact that the book is the legal standard under the Food and Drugs Act, enforced by Government agencies, the standards should be worked out and promulgated through Government agencies rather than having them delegated to other bodies. Objections obtain relative to this course of procedure because it is believed undesirable to place in the hands of a Governmental Department the formulation of standards of so important a publication as the $\mathrm{U}^{\top}$. S. Pharmacopoeia represents. Recently a plan has been suggested which endeavors to bridge over the conditions obtaining at present, namely, that the revision be placed in the hands of a committee of five, one from each of the following organizations: The American Pharmaceutical Association, $\mathcal{C}$. S. Department of Commerce, U. S. Treasury Department, U. S. Department of Agriculture and the American Medical Association.

In conclusion the Committee desires to thank all who assisted in the work and regrets exceedingly that the report does not go into greater detail on more subjects.

Respectfully submitted,

L. F. KEBLER, Chairman. 


\section{REPORT OF THE A. PH. A. COMMITTEE ON MODEL FOR MODERN LAWS PER- TAINING TO PHARMACY.*1}

The work of your Committee on Model for Modern Laws Pertaining to Pharmacy has made progress during the year, but it has not been completed. Many suggestions pertaining to detail have been made within the Conmittee, and also by members of the Voluntary Conference, which, almost without exception, will improve the Preliminary Draft ${ }^{2}$ submitted last year, and most of which will undoubtedly be accepted by the Committee. The more important and newer provisions have been widely discussed in pharmaceutical journals, at State meetings and otherwise, but in the opinion of the Committee they require even further discussion, criticism and suggestion for improvement before they are finally adopted. Some difference of opinion exists with reference to some of the features, which deserve every consideration. It has been decided that as briefly as possible we at this time submit the features upon which there has not been full agreement or regarding which further helpful advice is desired. We solicit the widest discussion on the following proposals contained in the Preliminary Draft:

rst. It is proposed in the Preliminary Draft to place the enforcement of all laws governing pharmacy and the drug business with the State Boards of Pharmacy under the direct supervision of a Drug Commissioner who is to be an appointee of the Board of Pharmacy. It will be noted that this makes the Board of Pharmacy a very powerful institution. Apart from the practical difficulties of enactment which need not be discussed here, the objection is raised that the Board of Pharmacy should be an Examining Board only, and that the enforcement f laws governing the pharmacist and the druggists should rest with other State Departments because other than pharmacists and druggists are also controlled by such laws and for the further reason that the enforcement will be more impartial. Those who favor complete control by a Drug Commissioner under the supervision of the Board of Pharmacy contend that only practical pharmacists can decide upon the correct enforcement of pharmacy and drug laws, and they further contend that the public welfare requires a greater and more general appreciation of the importance of pharmacy which with such intended authority for the Board of Pharmacy is given public expression.

2nd. The authority and standing of the Assistant Pharmacist are much drawn into question. The Preliminary Draft proposes, apart from general education, that an applicant for registration as Assistant Pharmacist should have either two (2) years of practical experience in pharmacy or in the alternative one (1) year of such practical experience and one (I) year of college work, and that he may be in charge of a pharmacy for not more than one (1) day each week. It is proposed that the requirements shall be either two years of practical pharmacy work or two years of college work, and then the far more important proposal is made that the Assistant Pharmacist shall be permitted to conduct a pharmacy without time restriction or limitation so long as a Registered Pharmacist has complete supervision which is not to be measured by the day or the week, but one ( 1 ) Registered Pharmacist at least being required for every pharmacy. The argument is advanced, that the Assistant Pharmacist should be given a higher standing with greater rights, this tending to increase the number of assistants, and to decrease the number who desire to conduct pharmacies of their own. In support the contention is made that if an Assistant Pharmacist is qualified to conduct a pharmacy for five (5) minutes, or for a day, he would be qualified to conduct it without any time restriction.

3rd. The Prelininary Draft proposes that the physician, dentist or veterinarian who would compound and dispense his own medicines shall show his qualification to practice pharmacy but would allow those who now are compounding and dispensing their medicines to continue to do so by registration without examination; only those who would newly so engage to be required

* Read before Section on Education and Legislation, A. Ph. A., and the Joint Session with the American Conference of Pharmaceutical Faculties and National Association of Boards of Pharmacy, Chicago Meeting, 1918.

${ }^{1}$ For the convenience of the members reference is made to the prior report of the Committee, April issue of the Journal, pp. 385-393, and also to reports of the Voluntary Conference to Draft Modern Laws Pertaining to Pharmacy: Volume IV, Journal A. PH. A., pp. 640 and 143 I ; Volume V, p. 1360; Volume VI, pp. 29 and 38.-EDIToR.

${ }^{2}$ See April Journal, A. Ph. A., pp. 385-393. 
to take an examination before the Board of Pharmacy in the theory and practice of pharmacy such as Assistant Pharmacists are required to pass. Specific exemption is made for doctors, etc., to provide drugs in cases of emergency which are administered to the patient in their presence. That the physician who would practice pharmacy should show qualification is very generally approved, but the objection is raised that legislation of the kind is unobtainable because of medical opposition. It is urged that organized medicine will never agree that a physician should in any respect be under the control of the Board of Pharmacy. Those who urge the need for such legislation say that the objection in part can be met by having the examination in pharmacy conducted by a Board of Pharmacy member, under the supervision of the Medical Boards. They contend that the needs for public safety should be the only consideration, and that the public through its legislature will be the first to demand such qualification when it learns that it does not now exist.

4th. The Preliminary Draft would accept as a fact that when a person has qualified as a Pharmacist, he remains so until the end of his day. It would do away with term re-registration, and in its place it would provide for the annual registration of all pharmacies. The objection is made that this does not enable the Board of Pharmacy to have accurate information regarding all within the State who are authorized to practice pharmacy, and the objection is further raised that a man, though registered as a Phårmacist, who has not practiced pharmacy for ten or twenty years, should not again be permitted to do so without first proving that he has retained his qualification to act as such.

${ }_{5}$ th. The Preliminary Draft would positively restrict the distribution at retail of a丩 drugs, medicines and poisons to persons who are registered, either as pharmacists, physicians, dentists or veterinarians and drug dealers, with the sole exception that drugs and poisons intended for agricultural, technical or industrial use, may be sold by others. The objection is raised, that no such exception should be made, and that if it is made, it would throw open the doors again for general distribution by unqualified persons. Having in mind that the intended law provides for the registration of drug dealers in districts where there are no registered pharmacists, the question is, whether such exception with reference to the sale at retail of drugs and poisons for agricultural, technical or industrial use is really necessary for public convenience.

6th. The Preliminary Draft provides a definition for Poisons and for Potent Drugs, and further provides that under the definition it shall be the duty of the Board of Pharmacy to name and publish lists of all poisons and potent drugs, these to include all so-called proprietary medicines which are found to contain what under the law would be a Poison or a Potent Drug, and it is then further provided that all such poison or potent drug content shall be shown on the label in ready-made medicines, and in the case of a physician's prescription either when filled by the pharmacist or when filled by the physician himself, shall be kept in the form of a prescription record, or in the alternative be shown on the label. Possibly no other single provision meets with more strenuous objection on the part of some and with equal strenuous approval on the part of others. Those who object to it say that it means merely a formula disclosure, that it is destructive of property rights and without compensating public benefit; those who favor the provision contend, first of all, that it is primarily for the public welfare. They say that it is frequently desirable and necessary for third persons to know what the active ingredients of a medicine may be. They advance the argument that no physician should be allowed to keep as his sole secret, without possible means of knowledge on the part of third persons, what strong drugs he may have dispensed and, from their point of view, it follows of necessity that no proprietary medicine manufacturer should be allowed to place in the hands of the consuming public what may be the most active of drugs, without some means of third persons knowing, both in case of emergency and in case of the ordinary matter of giving advice. Those who favor this partial formula disclosure contend that it is not destructive of property rights, because method of manufacture and content of non-potent drugs will give sufficient protection against competitive misuse.

We beg at this time to again point out that we understand the mission of this Committee to be the presentation of a Draft which includes what reasonably ought to be a part of up-todate laws pertaining to pharmacy. We do not believe that we should propose the unattainable, but neither do we believe that we should omit a needed present-day requirement simply because the first impression may be that its legislative enactment can not be secured. 
In conclusion we beg to urge upon pharmaceutical journals and upon pharmaceutical conventions, as well as the individual pharmacists, to help us with a free expression of opinion regarding the six proposals which are specially referred to herein, and which we again would briefly state as follows:

Ist. Shall the enforcement of all laws governing pharmacy be placed with the State Board of Pharmacy under the direct supervision of a Drug Commissioner?

2nd. Shall the authority and standing of the Assistant Pharmacist as such be materially increased?

3rd. Shall the physician who would practice pharmacy be required to prove his qualification as a pharmacist?

4th. Shall the pharmacist be relieved of re-registration, and shall there be an anmual registration of pharmacies?

5 th. Is it advisable to provide for an exception under which drugs and poisons for agricultural, technical or industrial use may be sold at retail by unqualified dealers?

6th. Should a modern law include a provision requiring that the poison or potent drug content of ready-made medicines be shown on the label, and that such poison or potent drug content in medicines prepared on physician's prescriptions be evidenced either by a written prescription or by record which the dispensing physician is required to keep?

Respectfully submitted,

WILLIAM C. ANDERSON,

H. V. ARNY,

JAMES H. Beal,

Chas. H. Huhn,

Frank H. I'REERICKS, Chairman.

\section{REPORT OF THE SPECIAL COMMITTEE ON REGULATIONS FOR TRANSPORTA- TION OF DRUGS BY MAIL.}

Your Committee begs to report that no steps have been taken during the past year by us or by any other organization to enact legislation on the transportation of drugs by mail. The war and conditions arising from it have so overshadowed this subject that quite properly no efforts along this line have been made. The mailing of drugs is still subject, therefore, to the original rulings of the Post Office Department, which depend on laws and regulations that are several years old. They have already been discussed by this Committee and their undesirable features made known to you. Let us continue to devote our full energies to winning the war, returning to the consideration of this subject when victory is ours.

Respectfully submitted,

B. I. MIURRAy, Chairman.

\section{REPORT OF THE GENERAI, MEMBERSHIP COMMITTFF.}

To the President and Members of the American Pharmaceutical Association:

The work of the General Membership Committee during the past year has been conducted along the usual lines. Special efforts have been made in Illinois on account of the convention being held in Chicago. In Minnesota, also, Dr. F. J. Wulling and Prof. F. I. Newcomb made a very earnest effort to secure new members which brought excellent results, while New York and Pennsylvania have more than kept up their usual quota of new memhers.

Although on the whole, the number of new members shows an increase over preceding years, yet a glanice over the appended statement will indicate many localities where membership work has lagged. The pressure of the conditions created by the war is largely responsible for this, and it is hoped that with the coming of brighter times a strong impetus will be given to the work of the Membership Committee throughout the country and that the Association may experience a rapid growth. 
NEW MEMBERS ELECTED SEPT. I, 1917, TO SEPT. I, 1918, AND GROUPED BY STATES AND MEMBERSHIP DISTRICTS.

District No. 1.

Connecticut.

Maine.......... o

New Hampshire. .

Vermont........ o

Massachusetts.... Io

Rhode Island.... o

Total.......
District No. 5.

Iowa......... 5

Missouri........ 6

Kansas......... 2

Minnesota... . . . 46 46

Nebraska.... . . . o

North Dakota... . 3

South Dakota... 3

Total.

65
District No. 2.

New Jersey. ..... 7

Virginia....... 8

West Virginia. . . .

New York. . . . . i it

Maryland.......

Dist. of Columbia 4

Pennsylvania.. . . 62

Delaware....... I

Total....... 158
District No. 3.

Illinois . . . . . . . 65

Ohio......... 16

Indiana ........ I I

Kentucky....... 2

Michigan...... 5

Wisconsin...... 3

Total..., ., 102
District No. 6.

California.

Colorado

Nevada

New Mexico

Utah

Total
District No 7 .

Idaho.

Oregon.

Alaska.

4

Washington.....

Total....... 6
District No. 4.

Alabama....... 3

Arkansas...... 3

Cuba......... 5

Florida........ 10

Georgia......... o

Louisiana....... 8

Mississippi...... 7

Panama........ o

Oklahoma....... 3

No. Carolina..... o

So. Carolina..... 2

'Tennessee....... 3

Texas......... 7

Porto Rico...... 3

Total ........5t

District No. 8.

Brit. America.... I

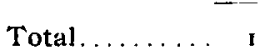

Philippines...... I

Foreign Country.. 4

II. S. Navy..... 2

Total...... 7 411

SUMMARY.

Membership August 15,1917

.2640

Losses from August 15, 1917 , to September 1, 1918:

By suspension. . . . . . . . . . . . . . $\ldots \ldots \ldots \ldots$

By resignation. . . . . . . . . . . . . . . . $\ldots \ldots 4$

By death. . . . . . . . . . . . $28 \ldots \ldots \ldots$

In the service and carried on the rolls without dues and without publications by action of the Association ............. 54

Total. ...........................

Less members reinstated $\ldots \ldots \ldots \ldots \ldots \ldots \ldots \ldots \ldots \ldots$

Net loss. . . . . . . . . . . . . . . . . . . . 407

New members elected August 15, 1917, to September 1, 1917.... 88

New members elected September 1, 1917, to September $1,1918 \ldots \ldots 4$ I

Total new members. . . . . . . . . . . . . . . . . . . . . 499

Net gain. . . . . . . . . . . . . . . . . $\ldots \ldots \ldots \ldots$

Total membership September 1, r918 $8 \ldots \ldots \ldots \ldots \ldots \ldots \ldots \ldots \ldots 2$

Respectfully submitted,

WM. B. DAY,

Chairman General Membership Commillec. 